\title{
A Comparison of a Surface Artefact Collection and Geophysical Prospection Information - Examples from the Vraný Micro-region, Distr. Kladno
}

\author{
Roman Křivánek $\mathrm{a}^{\mathrm{a}^{*}}$ \\ a'Institute of Archaeology of the Academy of Sciences of the Czech Republic, Prague, v.vi., Letenská 4, 11801 Prague 1, Czech Republic
}

\section{ARTICLE INFO}

\section{Article history:}

Received: 18 April 2012

Accepted: 31 August 2012

\section{Key words:}

surface artefact collection

geophysical prospection

hillfort

settlement

magnetometric survey

Vraný

\begin{abstract}
$A B S T R A C T$
Surface artefact collection and geophysical surveys are among the most intensively used non-destructive methods of archaeological survey in the Czech Republic. Only in a few cases, however, it has been possible to compare in detail the results of both methods, particularly in light of the small areal extents of current archaeogeophysical measurements. New possibilities for application of geophysical methods (particularly the magnetometric method) in full-scale archaeological sites now make it possible to compare these data with other large-scale realised non-destructive methods (aerial surveys or surface artefact collections). The enclosed contribution with examples from the Vraný micro-region attempt to compare the results of a systematically realised analytical surface artefact collection with new magnetometric survey results in the region. The examples should document how these two methods provide various qualitative and quantitative results and how they can complement the archaeological interpretation of the surveyed sites.
\end{abstract}

\section{Introduction}

The Vraný micro-region was one of the areas examined in the long-term project Ancient Landscape Reconstruction in Northern Bohemia (ALRNB; for example Zvelebil, Beneš, Kuna 1993; Zvelebil 1994). The ALRNB project ran from 1991 to 1995 as a collaboration between the Institute of Archaeology in Prague (Kuna et al.), the department in Most (Beneš et al.) and Sheffield University (Zvelebil et al.). Its aim was to trace the relationship between the settlement and landscape over a long-term perspective, from prehistory to the Early Medieval Ages. The main method of the project was surface artefact collection in two distinct areas (transects) of the northern part of Central and north-west Bohemia. The Vraný micro-region is located in the southern part of the NW-Bohemian transect.

\section{Description of the terrain}

The area of the research transect in NW Bohemia $(50 \times 10 \mathrm{~km})$ has been divided into 7 different ecozones (Sádlo, Peške

"Corresponding author. E-mail: krivanek@arup.cas.cz
1993). The southernmost ecozone Vransko included a border area between North and Central Bohemia dividing the upper Vltava and the lower Ohře catchment areas (for example, Beneš, Brůna, Křivánek 1993). The area around Vraný is flat, agricultural and a fairly dry region with sparse, straight streams which are cut into east-west oriented narrow valleys. The recent low density of the human settlement is concentrated along these streams and valleys. The bedrock of the micro-region around Vraný is formed by sandstones and limestones. The local landscape along the streams Vranský and Močidelský potok is formed by numerous terraces.

\section{Methodology}

\subsection{Surface artefact collection}

The analytical method of the surface artefact collection was also the main method over the entire period of the ALRNB project (1991-1995, in the NW Bohemian transect 19911996; see for example Kuna et al. 1993; Kuna 1994; 2000; 2008). The main reference unit was a sector, stint (sector in Czech terminology, stint in English terminology - see Kuna et al. 1993, Figure 6; Kuna 1994, Figure 22) - referenced area approx. $100 \times 100 \mathrm{~m}$ (also the area $25 \times 100 \mathrm{~m}$ during certain 
detailed surveys). This area was surveyed by 5 members of a working team (20 m intervals of the artefact collectors) in a N-S or S-N orientation of surveyed lines. Approx. 50\% of each chosen polygon (field) has been surveyed by this system of collection (changes of $100 \mathrm{~m}$ surveyed and non-surveyed field strips - traverses). A chronological and functional classification of the finds for each reference unit (sector/ stint) was then carried out. In the case of the transect in NW Bohemia this classification was performed by archaeologists from the region (Beneš, Meduna, Smrž).

\subsection{Geophysical survey}

The results of the previous surface artefact collection during the ALRNB project and the new aerial surveys in the region of NW Bohemia initiated several geophysical measurements. There was the possibility to use additional experience with archaeogeophysical surveys of enclosed or fortified settlements in Bohemia for the survey (see for example Křivánek, Kuna 1993; Krrivánek 1999; 2000; 2002; 2003; 2004a; 2004b; 2004c; 2006; Křivánek, Mařík 2009). In the case of the Vraný micro-region, magnetometric methods have been primarily conducted since 2007 (Křivánek 2008; 2010). Five different archaeological sites were surveyed in the vicinity of the Vranský potok stream east of Vraný. For magnetometric surveys of arable fields, 2 different types of magnetometers were used: a gradient variant of the caesium vapour magnetometer Smartmag SM-4g (Scintrex) and later also a 5-channel magnetometer system Magneto-Arch with fluxgate gradiometers FMG-650B (Sensys). In the case of the presented two examples, the density of the measured magnetometric data was $0.5 \times 0.2 \mathrm{~m}$.

\section{Results}

Two examples of archaeological sites over the left bank of the Močidelský and Vranský potok streams (Figure 1) were selected in order to compare the results of the two non-destructive methods. A small headland "Čertovka", an Eneolithic and Únětice culture enclosed settlement site was uncovered between these two sites in the 1950s (Žebera 1992; Knor 1954; 1957a; 1966). Only one other rescue archaeological research was consequently realised near Vraný over the last decade (Tomášek 2006). The results of the surface artefact collection in this microregion revealed a quite high and variable density of prehistoric, early medieval and medieval settlements (see Figures 2 and 5).

The first archaeological site in the position "Za humny" is located on a terrace above the stream with several abandoned sandstone quarries. The terrain here creates a natural headland above the recessed sandstone valleys. Surface artefact collection was conducted on the arable

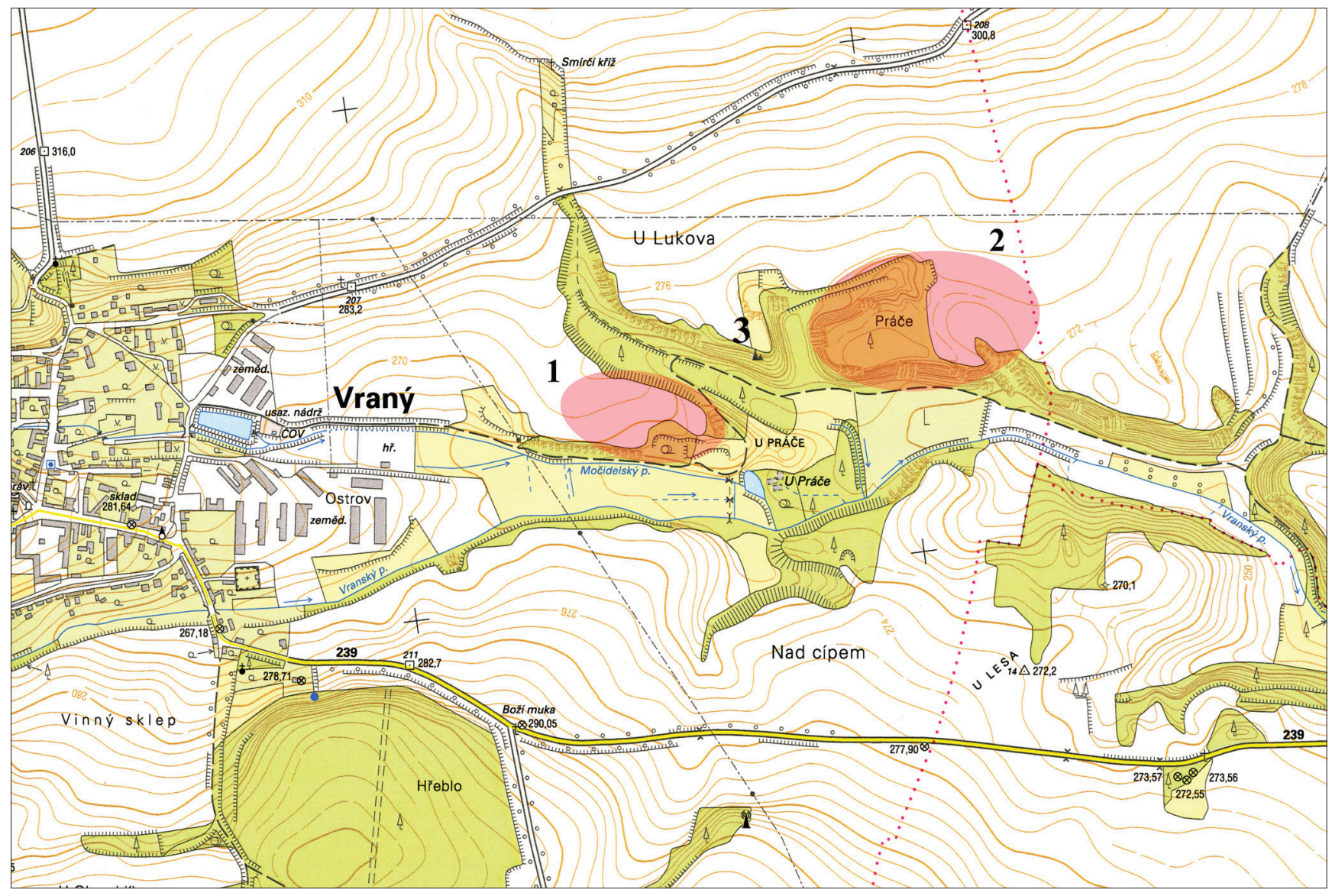

Figure 1. Location of two archaeological sites discussed in the text (1 - prehistoric polycultural settlement, 2 - Early Medieval hillfort Žižkaperk, 3 - uncovered an Eneolithic and Únětice culture enclosed settlement "Čertovka"). 


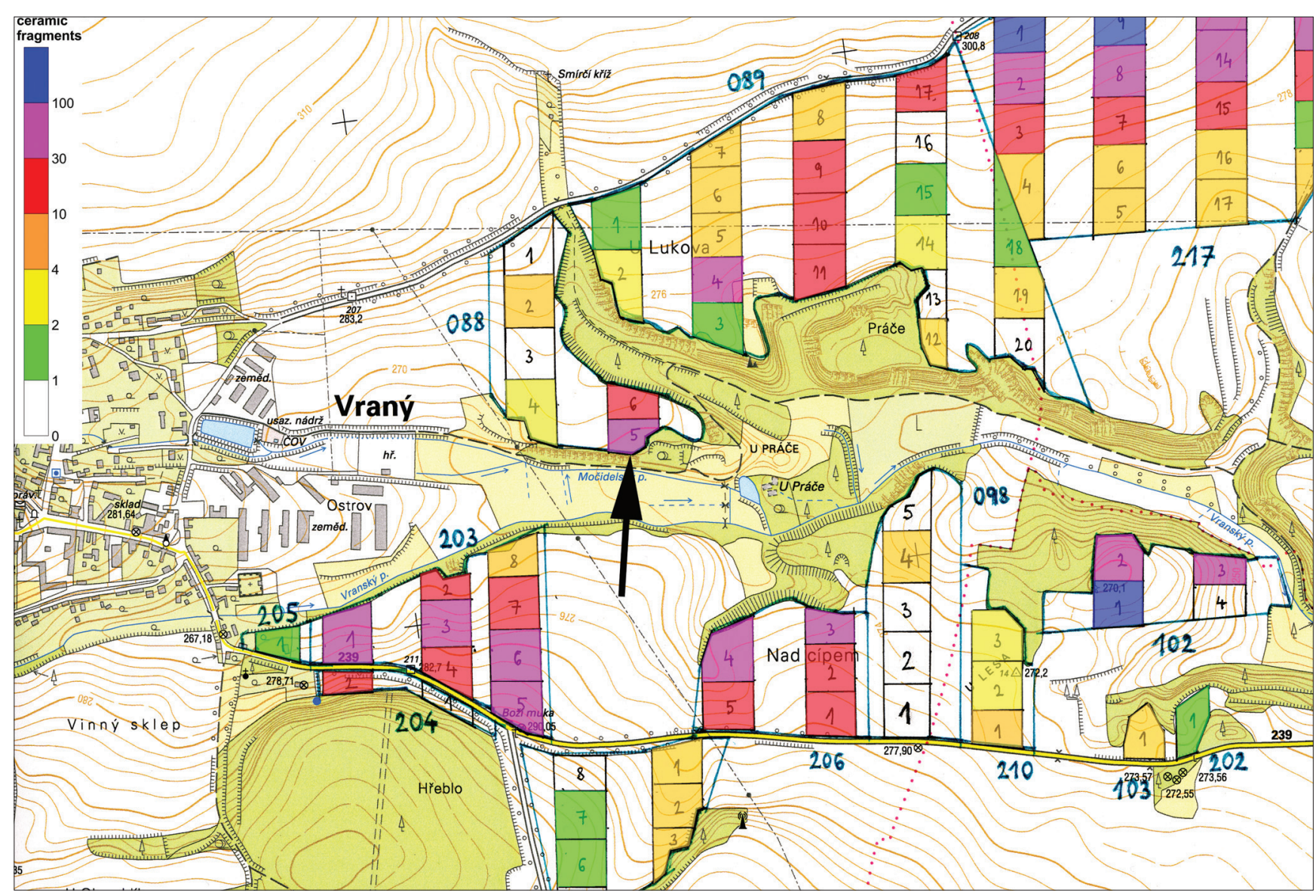

Figure 2. Distribution of prehistoric findings in combination with the results of the analytical method of surface artefact collection during the ALRNB project with the terrain situation on a segment of base map 1:10 000 (12-21-06) eastern from Vraný.

fields of the headland and in the western and northern flatter and open surroundings. More concentrated centres of various prehistoric settlements in the vicinity of the Močidelský potok stream can be identified from the map of the distribution of prehistoric finds (Figure 2). One of the most distinguished places (centres) of prehistoric settlement is situated on the monitored headland. Prehistoric settlement on the elevated terrace above the northern bank of the stream has been dated primarily to the Neolithic and from the Bronze age to the Hallstatt period (although the majority of the ceramic findings can only be classified in general as agricultural Prehistory). Based on the greater concentration of ceramic artefacts, it was assumed that the headland is also the largest concentration of settlement activities (particularly sunken objects). The possibility of enclosing the central area of the settlement could also not be excluded. A geophysical survey was conducted inside of the headland. Groups of isometric magnetic anomalies without any linear anomaly can be identified in the results of the magnetometric prospection (Figures 3 and 4). A magnetometric survey of the entire ploughed field on the headland did not confirm any enclosing or fortification of the settled area. Inside a strategic place above the stream, however, groups of different shaped magnetic anomalies were identified. More of these magnetic anomalies can probably identify sunken settlement features (possible small subrectangular houses and also small pits without a clear shape of structure), some smaller anomalies may be caused by recent metals in topsoil or local changes of soil (soil erosion) and geological bed rock. The distribution of potential sunken features is irregular although larger

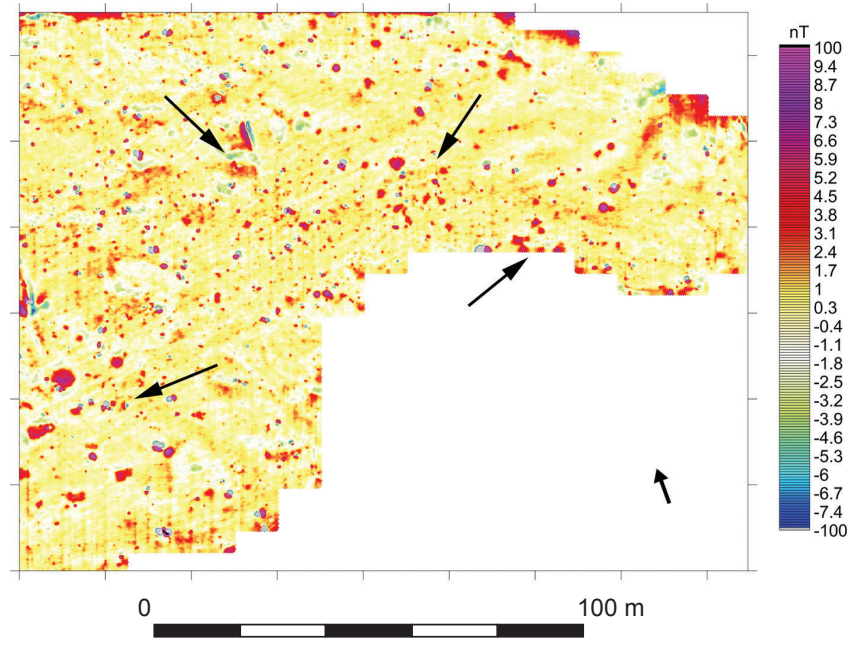

Figure 3. Identification of the sunken features, irregular intensity of the polycultural prehistoric settlement without any enclosure (surveyed area: approx. 1.4 ha; geophysical survey: Křivánek 2012). 


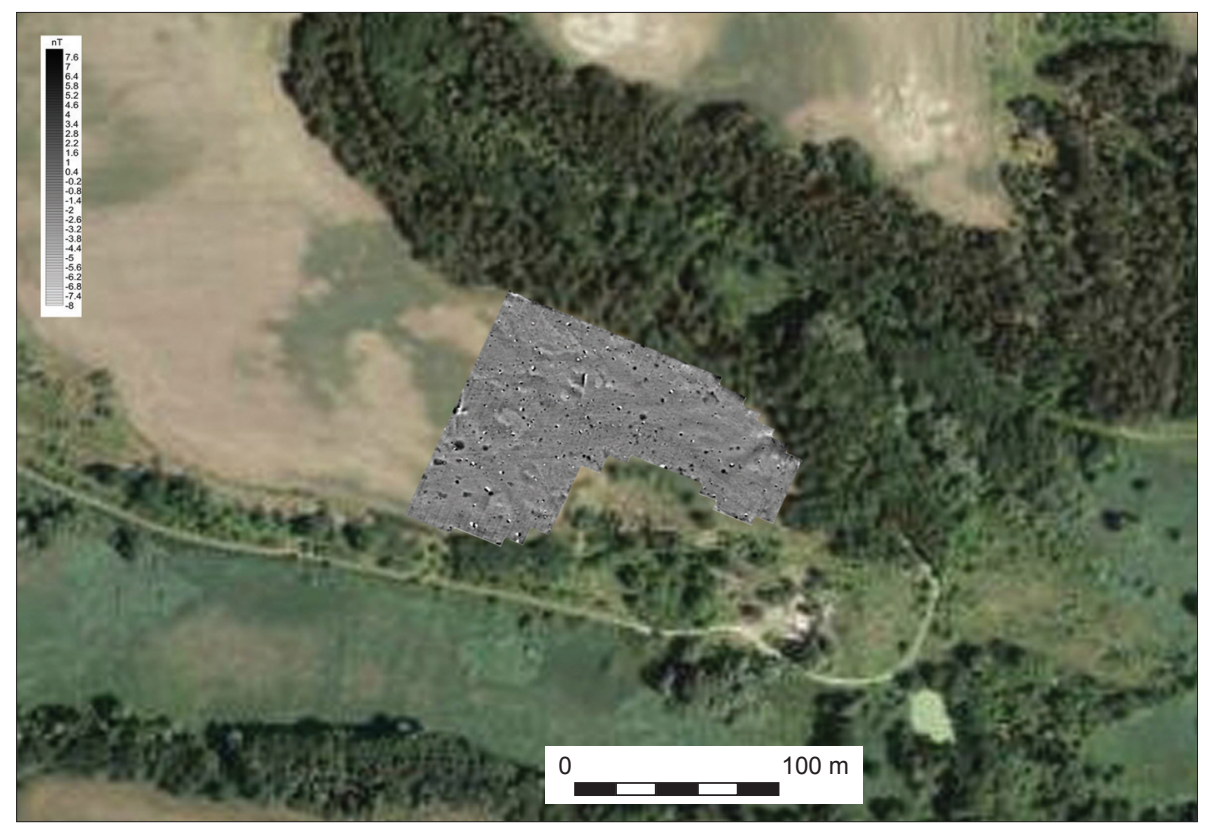

Figure 4. Combination of the results of the magnetometric survey with an aerial map (source: www.kontaminace.cenia.cz) of the natural headland over the left bank of the stream Močidelský potok.

magnetic anomalies (sunken features) seem to be more concentrated near the southern edge of the terrace. Smaller anomalies seem to be more concentrated to central part of headland and could indicate different use of area (possible relics of ploughed pit alignments and/or empty area).
The second archaeological site in the position known as "Žižkaperk" or "Práče" is located on a wide forested headland. Surface artefact collection and a geophysical survey were only conducted on arable fields in the eastern and northern surroundings of the forested sandstone headland

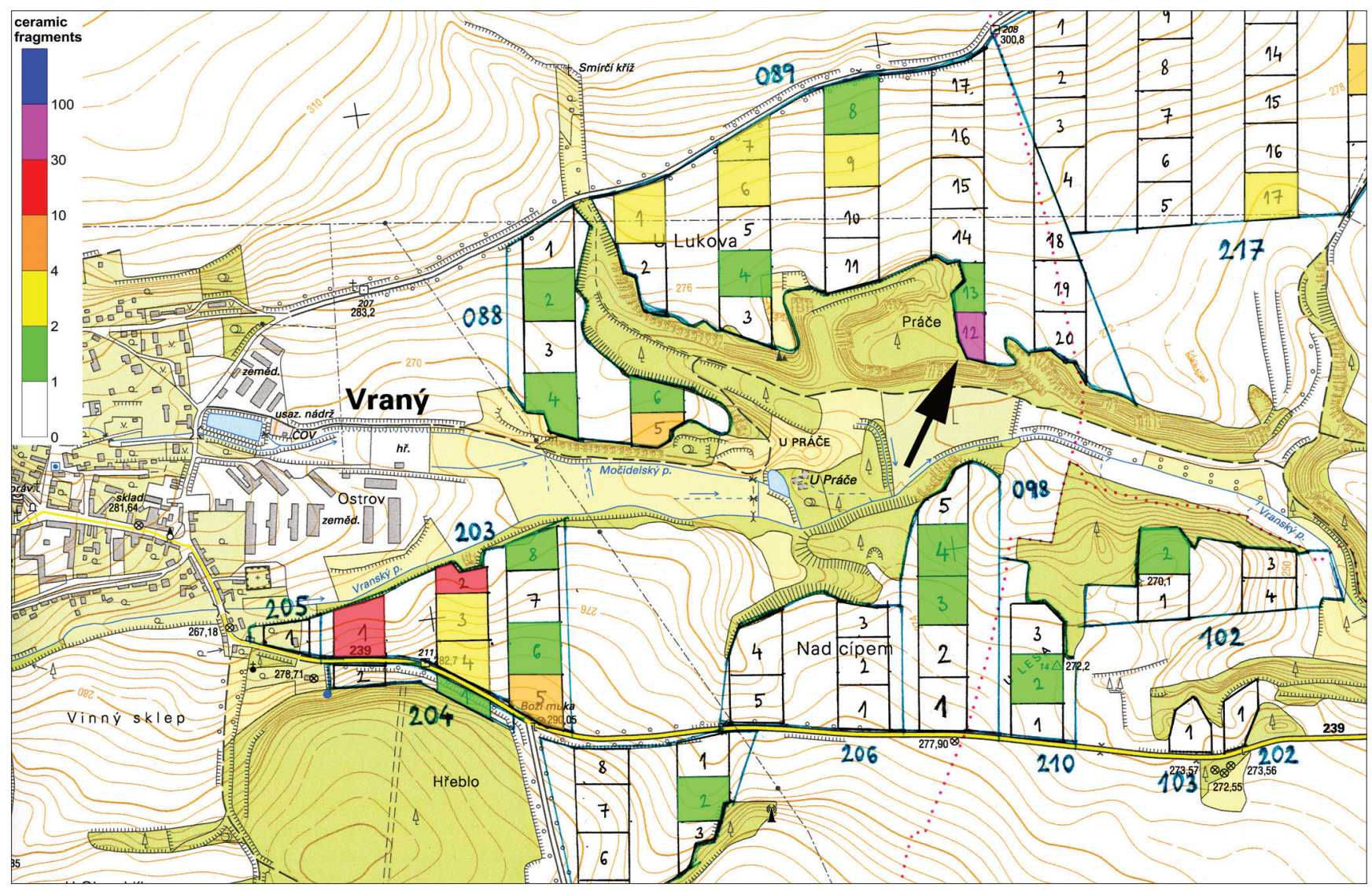

Figure 5. Distribution of Early Medieval findings in combination with the results of the analytical method of the surface artefact collection during the ALRNB project with the terrain situation on a segment of base map 1:10 000 (12-21-06) eastern from Vraný. 
terrace. Surface artefact collection was conducted on arable fields situated on the flat sandstone terrace. From the map of the distribution of early medieval findings, it is impossible to separate too concentrated relicts of certain early medieval activity or settlement (Figure 5). In the eastern vicinity of the forested headland, a distinguished smaller place with a concentrated early medieval settlement can only be identified. This concentration is situated near the southern edge of the elevated terrace above the northern bank of the stream. Ceramic findings were here classified from the Early Hillfort (EM-2) to the Late Hillfort (EM-4) Periods (several fragments of pottery were also classified as agricultural Prehistory). The presence of early medieval settlement in the forested headland also previously demonstrated the results of the archaeological trench of the archaeologist A. Knor in the 1950s (Knor 1955a; 1955b). Knor here assumed an Eneolithic and Early Medieval open (unfortified) settlement (Knor 1957a) although the site was not studied later by archaeologists. A new geophysical survey was conducted in the fields east and north-east of the headland (visible relics of unclear linear crop marks on new aerial photographs). Two curved linear anomalies and groups of isometric magnetic anomalies can be identified in the results of the magnetometric prospection (Figures 6 and 7). A magnetometric survey in the outer part of very probable early medieval hillfort changed previous archaeological ideas regarding the scale, extent and intensity of the fortified settlement. The result of geophysical prospection confirmed (at least) 3 different fortified parts of the hillfort. The forested central area of the hillfort on the headland (with in all probability another relict of the fortification, rampart and possible ditch) had two outer baileys. These two outer fortification systems (ditches) and settlement concentrated behind ditches in front of the headland are not visible at present on the surface

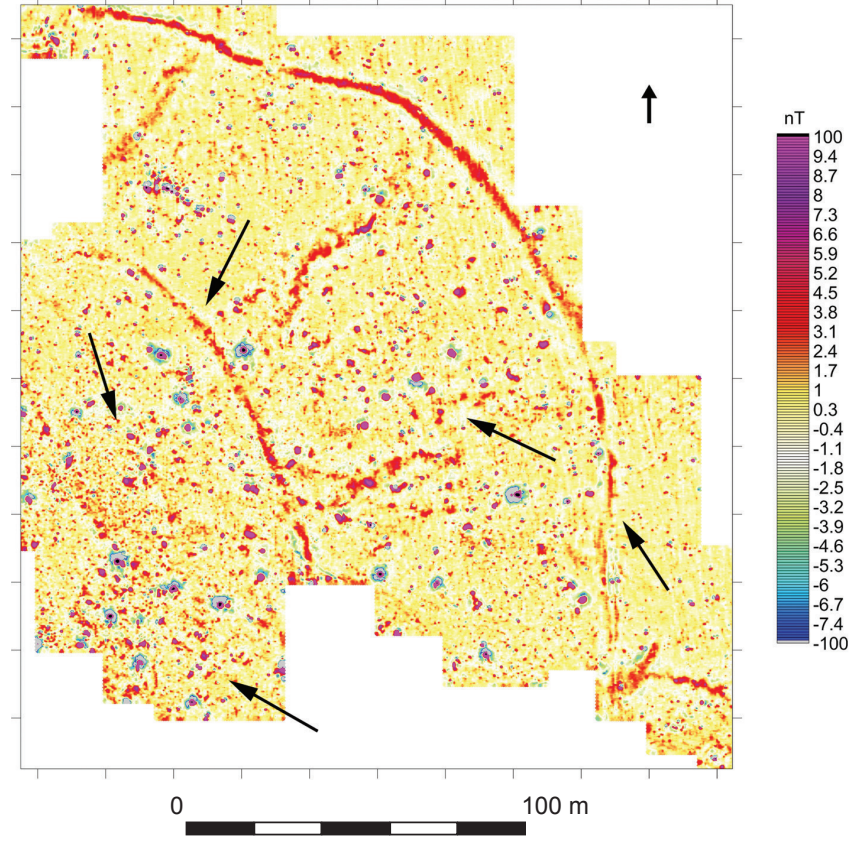

Figure 6. Identification of two unknown outer baileys of the early medieval hillfort with the inner settlement (surveyed area: approx. 3.1 ha; geophysical survey: Křivánek 2012).

of the ploughed fields. Most of magnetic anomalies can here probably identify sunken settlement features (mainly Early Medieval settlement but we cannot exclude also some prehistoric settlement activity), some smaller and high magnetic anomalies may be caused also by burned materials, relics of production features or recent metals. The turning of linear magnetic anomaly from outer ditch to east direction could indicate some entrance to hillfort or modern communication (local sandstone quarries).

Figure 7. Combination of the results of the magnetometric survey with an aerial map (source: www.kontaminace.cenia.cz) of the wide forested headland over the left bank of the stream Vranský potok.

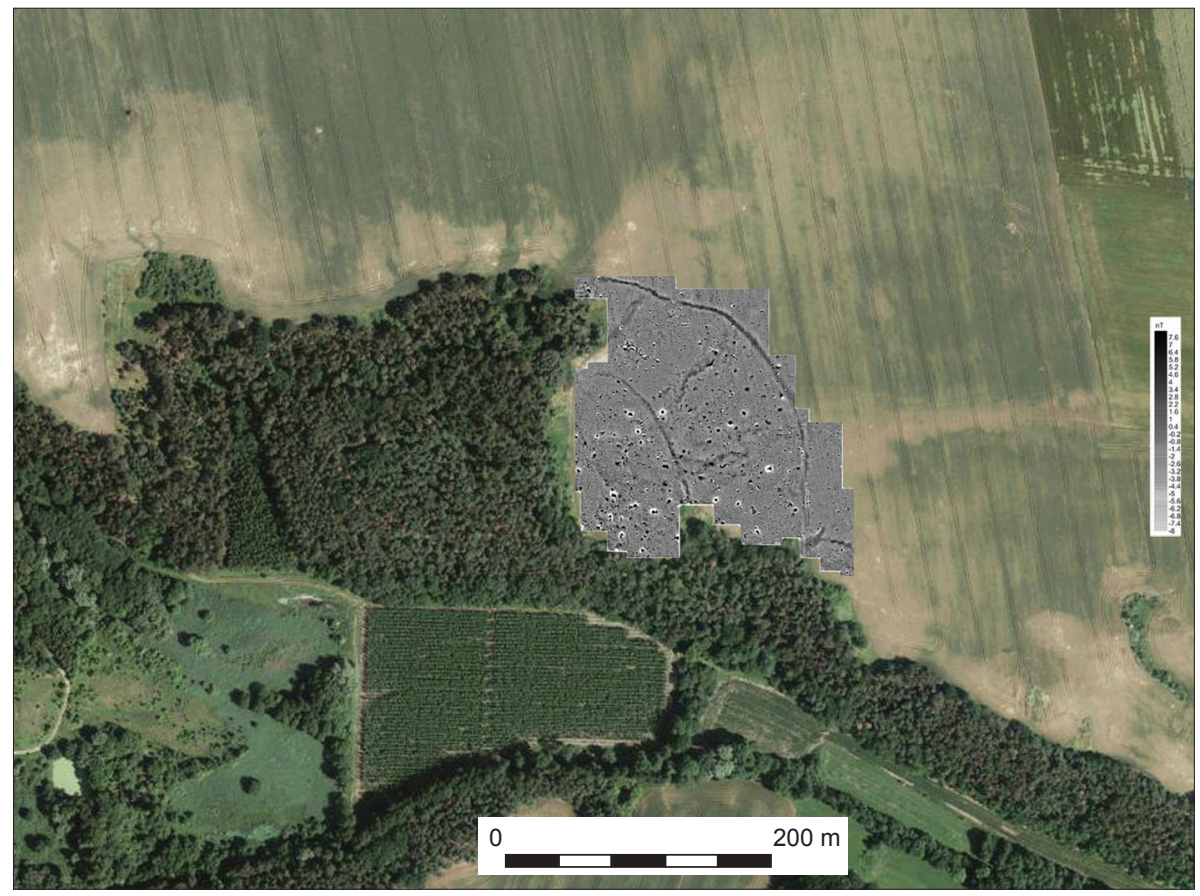




\section{Discussion}

The two selected examples represent a simple way of comparing the results of systematic surface artefact collection and geophysical measurements of the same sites. With regard to the results of the new geophysical measurements, the results of earlier realised surface artefact collection have a low density of data. The system of collection (changes of $100 \mathrm{~m}$ of the surveyed and non-surveyed field strips - traverses) and the size of the reference unit (stint $100 \times 100 \mathrm{~m}$ ) can also be seen as a disadvantage for more accurate identification of the spatial distribution of the findings. On the other hand, the results of the system of collection during the ALRNB project in the case of Vraný both identified here represented archaeological sites. It is only a matter of how the results of surface artefact collection reflect dating, spatial distribution and intensity of settlement and also how are affected by often complicated archaeological transformations (for more se for example Beneš 1998; Smrž, Kuna, Káčerik 2011). The results here could indicate the possible extent of anthropogenic activities or settlement but also variable level of preservation of subsurface layers due to ploughing, soil erosion or other modern changes of landscape and land use. The results of the magnetometric surveys consequently confirmed different types of settlement activity (a polycultural prehistoric settlement area without an enclosure and an early medieval hillfort). The magnetometric survey here also identified places and areas of sunken probably settlement features but some parts of measured areas could be also affected by agricultural activity, soil erosion and landscape changes (abandoned quarries, ploughed roads, parcelations,...). Clear and complete pit alignments documenting houses or only near surface settlement remains were not distinguished on the arable fields. The wide distribution of ceramic findings (and narrow distribution of identified sunken features) could be at present also affected by long-term ploughing, medieval or modern soil re-deposition and/or fertilization of fields.

\section{Conclusion}

The examples of a combination of two non-destructive methods in the Vraný micro-region reveal how positive results for the systematically realised analytical surface artefact collection could be effectively verified by the magnetometric prospection method. The enclosed results also document different possibilities as the limitations of both methods. The results are different but both methods depend on the state of subsurface preservation of the archaeological situations and the intensity of the modern landscape changes. In the case of the Vraný micro-region, this will probably be conducted by magnetometric measurements at other places along the stream Vranský potok in the future.

\section{Acknowledgements}

This article was supported by an internal project of the Institute of Archaeology of the Academy of Sciences of the
Czech Republic, Prague, v.v.i. "Enclosed areas in prehistoric and early medieval" (research project: 80020508).

\section{References}

BENEŠ, J., BRŮNA, V., KŘIVÁNEK, R. 1993: The changing landscape of North-West Bohemia during the last two centuries - Změny krajiny severozápadních Čech za poslední dvě století, Památky archeologické 84/2, 142-149.

BENEŠ, J. 1998: Keramika, ornice a relief. Výzkum polykulturního osídlení v Kozlech, o. Louny (SZ Čechy), Archeologické rozhledy 49, 614-624, 646-648.

KNOR, A. 1954: Zpráva o výzkumu eneolitické a únětické výšinné osady "Na čertovce" ve Vraném, okr. Slaný, v r. 1953, Referáty Liblice 1953, 4.

KNOR, A. 1955a: Vraný, okr. Slaný. Zjišt'ovací a záchranné výzkumy v r. 1955. MS. Excavation report nr. 2745/55. Deposited at: Archiv ARÚ AV ČR, Praha.

KNOR, A. 1955b: Vraný, okr. Slaný. Výzkum 1955. MS. Excavation report nr. 2745/55. Deposited at: Archiv ARÚ AV ČR, Praha.

KNOR, A. 1957a: Nová hradištní sídliště na Kladensku a Slánsku, Památky archeologické 48, 58-98.

KNOR, A. 1957b: Eneolitická a únětická opevněná osada ve Vraném na Slánsku: (výzkum 1953-1956). Referáty Liblice 1956, 51-58.

KNOR, A. 1966: Halstat énéolithique et de la civilisation d'Únětice a Vraný (Boheme). In: Filip, J. (Ed.): Investigations archéologiques en Tchécoslovaquie. VIIéme Congrès international des Sciences préhistoriques et protohistoriques à Prague, 1966, Academia, Praha, 88-89.

KŘIVÁNEK, R. 1999: Přehled využití geofyziky ArÚ Praha na archeologických lokalitách ve středních Čechách v letech 1994-1998, Archeologie ve střednich Čechách 3, 213-234.

KŘIVÁNEK, R. 2000: Způsoby využití geofyzikálních měření jako metody průzkumu hradišt', Archeologie ve střednich Čechách 4, 489-503.

KŘIVÁNEK, R. 2002: Nedestruktivní geofyzikální průzkumy zaniklých fortifikací opevněných lokalit, Muzejni a vlastivédná práce. Časopis Společnosti prátel starožitností 3/2002, 180-187.

KŘIVÁNEK, R. 2003: Contribution of geophysical measurements for survey and protection of hillforts. In: Altan, M. O. (ed.): Proceedings of the XIXth International Symposium CIPA 2003, New Perspectives To Save Cultural Herritage. Antalya (Turkey) 30 September - 04 October, 2003, CIPA Istanbul, 389-391.

KŘIVÁNEK, R. 2004a: Geofyzikální metody. In: Kuna, M. (ed.): Nedestruktivni archeologie. Teorie, metody a cíle. Academia, Praha, $117-183$.

KŘIVÁNEK, R.. 2004b: Geophysical prospection. New perspectives for settlement studies in Bohemia. In: Gojda, M. (ed.): Ancient Landscape, Settlement Dynamics and Non-Destructive Archeology - Czech research project 1997-2002. Academia, Praha, 39-71.

KŘIVÁNEK, R. 2004c: Přehled využití geofyzikálních měření ARÚ Praha na archeologických lokalitách ve Středních Čechách v letech 1999-2003, Archeologie ve středních Čechách 8, 365-408.

KŘIVÁNEK, R. 2006: Magnetometric prospection of various types of large ditched enclosures in Bohemia, Archaeological prospection 13/1, 25-43.

KŘIVÁNEK, R. 2008: Geofyzikální měření ARÚ Praha na archeologických lokalitách v roce 2007. In: Zprávy ČAS Supplément 71 - Archeologické výzkumy v Čechách 2007, sborník referátů z informačního kolokvia, $12-15,52-53$.

KŘIVÁNEK, R. 2010: Geofyzikální měření ARÚ Praha na archeologických lokalitách v roce 2009. In: Zprávy ČAS Supplément 78 - Archeologické výzkumy v Čechách 2009, sborník referátů z informačního kolokvia, 16-19.

KŘIVÁNEK, R., KUNA, M. 1993: Geophysics within the ALRNB Landscape \& Setlement programme: a Neolithic circular enclousure at Vinoř - Geofyzika v projektu ALRNB - krajina a sídla: neolitický kruhový př́kop ve Vinoři, Památky archeologické 84/2, 93-95.

KŘIVÁNEK, R., MAŘíK, J. 2009: Early Medieval stronghold Libice nad Cidlinou. An example of use of geophysical methods in systematic non-destructive archaeological project. In: ArcheoSciences, revue 
d'archéométrie, suppl. 33 (Mémorie du sol, espace des hommes), Presses de Universitaires de Rennes, Rennes, 93-95.

KUNA, M. 1994: Archeologický výzkum povrchovými sběry. Zprávy ČAS - Supplément 23, Praha.

KUNA, M. 2000: Surface artefact studies in the Czech Republic. In: Bintliff, J., Kuna, M., Venclová, N. (Eds.): The future of surface artefact survey. Sheffield, 29-44.

KUNA, M. 2008: K metodě analytických povrchových sběrů. In: Černá, E., Kuljavceva Hlavová, J. (Eds.): Archeologické výzkumy v severozápadnich Čechách v letech 2003-2007, Sborník k životnímu jubileu Zdeňka Smrže. ÚAPPSZČ Most, Most, 399-408.

KUNA, M., ZVELEBIL, M., FOSTER, P. J., DRESLEROVÁ, D. 1993 Field survey and landscape archaeology research design: methodology of a regional field survey in Bohemia - Povrchový průzkum a krajinná archeologie: program a metodika regionálního průzkumu v Čechách, Památky archeologické 84/2, 110-130.
SÁDLO, J., PEŠKE, L. 1993: Environmental conditions within the ALRNB research transects - Přírodní prostředí ve studovaných transektech ALRNB, Památky archeologické 84/2, 95-101.

SMRŽ, Z., KUNA, M., KÁČERIK, A. 2011: Archeologie mizející krajiny. Terénní průzkum předpolí Dolů Nástup Tušimice, Památky archeologické 102, 159-216.

TOMÁŠEK, M. 2006: Vraný u Slaného: nález hrobu únětické kultury, Archeologie ve střednich Čechách 10/1, 379-383.

ZVELEBIL, M. 1994: Koncept krajiny: šance pro archeologii. In: Archeologie a krajinná ekologie. Nadace Projekt Sever, Most, 20-36.

ZVELEBIL, M., BENEŠ, J., KUNA, M. 1993: Ancient Landscape Reconstruction in Northern Bohemia: Landscape and Settlement Programme - Projekty rekonstrukce staré kulturní krajiny v severní části Čech: krajina a sídla, Památky archeologické 84/2, 133-137. 
